\title{
Perancangan Antarmuka Sistem Pakar Penyakit Padi Berbasis Web
}

\section{Design for Expert System Interface of Web-Based Rice Disease}

\author{
Febrianta Surya Nugraha ${ }^{1}$, Febryan Hari Purwanto ${ }^{2}$, Mayadi ${ }^{3}$, Miftahul Huda ${ }^{4}$, \\ Muhammad Misbahul Munir ${ }^{5}$, Riski Tri Puji ${ }^{6}$ \\ ${ }^{1}$ Mahasiswa Magister Teknik Informatika Universitas AMIKOM Yogyakarta, \\ ${ }^{2}$ Akademi Farmasi Al-Fatah Bengkulu, ${ }^{3}$ STMIK Bumigora Mataram \\ ${ }^{4}$ SMA YPM Diponegoro Kutai Kartanegara, ${ }^{5}$ Primemobile Yogyakarta \\ ${ }^{6}$ Creatia Indonesia \\ ubingg@gmail.com ${ }^{1}$, fharipurwanto@gmail.com ${ }^{2}$, mayadi.yadot23@ gmail.com ${ }^{3}$,

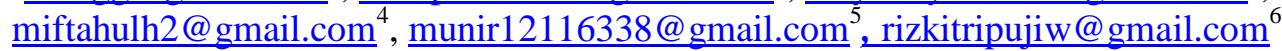

\begin{abstract}
Abstrak
Antarmuka merupakan salah satu bagian dari perangkat lunak yang berhubungan langsung dengan pengguna. Pengguna berinteraksi dengan sistem perangkat lunak melalui antarmuka pengguna. Penelitan terdahulu pada sistem pakar penyakit padi hanya terbatas pada pengujian apakah sistem pakar dapat berjalan tanpa memperhatikan aspek antarmuka pengguna. Tujuan dari penelitian ini adalah merancang antarmuka pengguna (user interface) pada sistem pakar penyakit padi dengan berbasis web. Tahapan-tahapan pada penelitian ini adalah melakukan analisis calon pengguna dan pihak terkait yang dapat menjadi kandidat pengguna, pemilihan platform pengembangan yaitu berbasis web, analisis user environment atau lingkungan pengguna yang berkaitan dengan basis web, perancangan struktur menu, perancangan antarmuka, dan evaluasi. Hasil rancangan dievaluasi dengan menggunakan model pendekatan evaluasi heuristik penggunaan (usability heuristics) yang diperkenalkan oleh Jacob Nielson untuk mengetahui kekurangan dan saran rancangan antarmuka sistem pakar. Hasil dari evaluasi heuristik penggunaan adalah penggunaan kata berbahasa Inggris seperti username, password, FAQ serta penggunaan kata tidak baku yaitu diagnosa pada aspek kesesuaian antara sistem dan dunia nyata. Kurangnya ikon pada menu dan perbedaan tombol dan teks yang kurang jelas pada aspek memahami lebih baik daripada mengingat. Pesan kesalahan yang muncul kurang detail.
\end{abstract}

Kata Kunci-Antarmuka, Sistem Pakar, Web, Evaluasi Heuristik

\begin{abstract}
The interface is one piece of software that contacts directly with user. The user interacts with software system through user interface. Previous research on rice disease expert systems is limited to testing whether the expert system works without regard to the user interface aspect. The purpose of this research is to make design of user interface on web-based expert system of rice disease. The stages of this research are to analyze potential users and related parties that can be user candidates, web-based development platform selection, user environment analysis or user environment related to web base, menu structure design, interface design, and evaluation. The design results are evaluated using a usability heuristics approach model introduced by Jacob Nielson to find out the drawbacks and suggestions of the expert system interface design. The result of a heuristic usability evaluation are the use of English words such as usernames, passwords, $F A Q$ and non-standard word usage diagnosa on the aspect of match between system and the real world. Lack of icons on the menu and the differences in buttons
\end{abstract}


Perancangan Antarmuka Sistem Pakar Penyakit Padi ...

and text are less clear on aspects of recognition rather than recall. The appearance of error message is less detailed.

Keywords - Interface, Expert System, Web, Heuristic Evaluation

\section{PENDAHULUAN}

Antarmuka merupakan salah satu bagian dari perangkat lunak yang berhubungan langsung dengan pengguna. Pengguna berinteraksi dengan sistem perangkat lunak melalui antarmuka pengguna. Sistem pakar adalah sistem komputer yang ditujukan untuk meniru semua aspek (emulates) kemampuan pengambilan keputusan (decision making) seorang pakar. Sistem pakar memanfaatkan secara maksimal pengetahuan khusus selayaknya seorang pakar untuk memecahkan masalah [1]. Antarmuka (user interface) merupakan mekanisme yang digunakan oleh pengguna dan sistem pakar untuk berkomunikasi. Antarmuka penerima informasi dari pengguna dan mengubahnyakedalam bentuk yang dapat diteruma oleh sistem. Selain itu antarmuka menerima informasi dari sistem dan menyajikannya kedalam bentuk yang dapat dimengerti oleh pengguna [2].

Human Computer Interaction adalah disiplin ilmu yang mempelajari bagaimana manusia berinteraksi dengan komputer termasuk tugas-tugas yang menjadi pengikat diantara keduanya. Pembelajaran interaksi manusia-komputer ini akan menilai suatu perangkat lunak dari faktor user friendly, yaitu sistem harus dirancang untuk kemudahan yang mempertimbangkan tingkat kemampuan pengguna terhadap teknologi informasi dan error free, yaitu tingkat error masih dalam batas yang layak untuk digunakan. Untuk Mencapai hasil dengan kriteria tersebut, perangkat lunak harus dirancang sesuai dengan kebutuhan. Hal yang rumit sebisa mungkin disembunyikan dari pengguna. Penampilan antar muka yang indah bukan jaminan selalu baik, bahkan desain antarmuka yang sederhana dapat menjadi lebih efektif jika sesuai dengan kebutuhan pengguna [3].

Evaluasi heuristik adalah jenis antarmuka pengguna atau inspeksi penggunaan di mana individu atau tim individu, mengevaluasi spesifikasi, prototipe, atau produk terhadap daftar singkat pengunaan dari prinsip pengalaman pengguna atau bidang yang menjadi perhatian. Metode evaluasi heuristik adalah salah satu metode yang paling umum dalam desain yang berpusat pada pengguna untuk mengidentifikasi masalah pengunaan, walaupun dalam beberapa kasus, apa yang orang anggap sebagai evaluasi heuristik dapat dikategorikan sebagai pemeriksaan yang lebih baik dilakukan oleh ahli, karena heuristik dicampur dengan prinsip, keyakinan pribadi dan pengetahuan tentang penggunaan. Heuristik adalah aturan atau prinsip yang disederhanakan. Daftar heuristik dimaksudkan sebagai alat bantu untuk mengingat bagi evaluator. Tabel 1 adalah daftar heuristik yang mungkin diberikan kepada tim evaluator untuk mengingatkan mereka tentang area masalah potensial [4].

Tabel 1. Daftar Heuristik [4].

\begin{tabular}{cl}
\hline No & \multicolumn{1}{c}{ Evaluasi Heuristik } \\
\hline 1 & Visibilitas status sistem \\
\hline 2 & Kesesuaian antara sistem dan dunia nyata \\
\hline 3 & Kendali dan kebebasan pengguna \\
\hline 4 & Standar dan konsistensi \\
\hline 5 & Pencegahan Kesalahan \\
\hline 6 & Memahami lebih baik daripada mengingat \\
\hline 7 & Fleksibilitas dan efesiensi \\
\hline 9 & Estetika dan desain yang minimalis \\
\hline 10 & Pertolongan pengguna untuk mengenali, berdialog dan memperbaiki kesalahan \\
\hline
\end{tabular}

Beberapa penelitian terdahulu tentang sistem pakar antara lain, Azizah et all (2013) yang berjudul Rancang Bangun Aplikasi Sistem Pakar Diagnosa Penyakit Tanaman Padi Berbasis Web [5], sistem pakar dirancang berbasis aturan dengan metode inferensi forward 
chaining dan backward chaining serta diimplementasikan ke dalam bentuk website yang bertujuan untuk memberikan kemudahan akses bagi pengguna. Saepulloh et al (2016) yang berjudul Pengembangan Sistem Pakar Diagnosis Penyakit dan Hama pada Tanaman Padi Varietas Sarinah Berbasis Android [6], sistem pakar yang menggunakan metode inferensi forward chaining ini khusus mendiagnosis hama dan penyakit pada tanaman padi serta memberikan informasi mengenai solusi pengobatan atau penanggulangan pada serangan hama dan penyakit. Sistem pakar telah berhasil diuji dengan metode Black Box dan telah divalidasi oleh pakar tanaman padi. Triono dan Tristono (2016) yang berjudul Expert System Identification of Pest and Diseases of Rice using Html5 [7], pada penelitian ini menggunakan penalaran berbasis peraturan yang diimplementasikan pada basis web dengan bahasa pemrograman PHP dan HTML5. Pada penelitian-penelitian diatas belum membahas tentang perancangan antarmuka dan evaluasi penggunaan (usability). Penelitan terdahulu pada sistem pakar penyakit padi hanya terbatas pada pengujian apakah sistem pakar dapat berjalan tanpa memperhatikan aspek antarmuka pengguna.

Beberapa penelitian terdahulu tentang evaluasi heuristik user interface antara lain sebagai berikut, Firmansyah (2016) yang berjudul Evaluasi Heuristik Pada Desain Interfae Aplikasi My Indihome [8], penelitian ini memfokuskan pada evaluasi heuristik pada desain aplikasi antarmuka dari My IndiHome versi 5.1 pada platform Android untuk menentukan sejauh mana kegunaan desain antarmuka. Hasil dari penelitian ini adalah bahwa antarmuka aplikasi MyIndiHome secara umum telah mampu memberikan kenyamanan bagi pengguna tetapi ada beberapa hal yang perlu diperbaiki dalam hal kemudahan penggunaan dan keakuratan informasi. Savitri dan Ispani (2015), yang berjudul Review Desain Interface Aplikasi Sopppos Menggunakan Evaluasi Heuristik [9], penelitian ini menggunakan evaluasi interaksi manusia komputer yang bernama evaluasi heuristik yang diperkenalkan oleh Molich dan Nielsen. Berdasarkan hasil evaluasi menyatakan bahwa secara umum desain interface dan kemudahan pengguna (usability) dari aplikasi SOPPPOS cukup baik, namun masih ada beberapa hal yang perlu diperbaiki terutama dalam karakteristik kemudahan penggunaan. Pattiasina et al (2014) yang berjudul Pembuatan Dan Evaluasi Kemudahan Turis Dalam Menggunakan Aplikasi Baronda Ambon Travel Guide [10], penelitian ini bertujuan menciptakan aplikasi pariwisata pulau Ambon dan bagaimana mengevaluasi aplikasi tersebut sehingga memiliki tingkat usability yang baik sehingga mudah digunakan oleh turis baik domestik maupun internasional. Baronda Ambon yang telah dievaluasi dengan menggunakan heuristic usability menunjukan adanya kekurangan dalam beberapa hal, akan tetapi hasil penelitian terhadap 42 responden menunjukan bahwa kelemahan-kelemahan yang dimiliki oleh Baronda Ambon tidak mengurangi performa Baronda Ambon yang dikategorikan dalam predikat Baik menurut skala Likert.

Tujuan dari penelitian ini adalah merancang antarmuka pengguna (user interface) pada sistem pakar penyakit padi dengan berbasis web. Hasil rancangan dievaluasi dengan menggunakan model pendekatan evaluasi heuristik penggunaan (usability heuristics) yang diperkenalkan oleh Jacob Nielson untuk mengetahui kekurangan dan saran rancangan antarmuka sistem pakar.

\section{METODE PENELITIAN}

Tahapan-tahapan pada penelitian ini adalah melakukan analisis calon pengguna dan pihak terkait yang dapat menjadi kandidat pengguna, pemilihan platform pengembangan yaitu berbasis web, analisis user environment atau lingkungan pengguna yang berkaitan dengan basis web, perancangan struktur menu, perancangan antarmuka, dan evaluasi. Pada tahapan analisis calon pengguna dan pihak terkait, peneliti mengumpulkan data-data calon pengguna yang berkaitan dengan sistem pakar penyakit padi. Pada tahap pemilihan pengembangan platform berbasis web, peneliti mencari kelebihan maupun kekurangan dalam pemilihan patform berbasis web. Pada tahap analisis user environment, peneliti mencari data-data yang berhubungan dengan perangkat lunak berbasis web. Pada tahap perancangan struktur menu dan antarmuka, 
peneliti membuat rancangan berdasarkan kebutuhan pengguna dan fitur-fitur tambahan yang akan direncanakan. Pada tahap evaluasi, dilakukan evaluasi heuristik penggunaan (usability heuristics) dengan menggunakan penguji sebagai evaluator. Tahapan penelitian dapat dilihat pada gambar 1 berikut ini.

\begin{tabular}{|l|l|}
\hline 1 & $\begin{array}{l}\text { Analisis calon pengguna dan pihak } \\
\text { terkait }\end{array}$ \\
\hline 2 & Pemilihan platform \\
\hline 3 & - Analisis user environment \\
\hline 4 & Perancangan struktur menu \\
\hline 5 & - Perancangan antarmuka \\
\hline 6 & - Evaluasi \\
\hline
\end{tabular}

Gambar 1. Tahapan Penelitian

\subsection{Analisis Calon Pengguna}

\section{HASIL DAN PEMBAHASAN}

Menurut data sensus pertanian tahun 2013 dari badan pusat statistik, petani di Indonesia berjumlah 26.135.469, rincian tabel data petani berdasarkan umur dapat dilihat pada tabel 2 berikut ini [11].

Tabel 2. Petani Berdasarkan Kelompok Umur dan Jenis Kelamin

\begin{tabular}{|c|c|c|c|}
\hline \multirow{2}{*}{ Kelompok Umur } & \multicolumn{3}{|c|}{ Jenis Kelamin Petani Utama } \\
\hline & Laki-laki & Perempuan & Jumlah \\
\hline$<15$ & 2,639 & 423 & 3,062 \\
\hline $15-24$ & 208,848 & 21,029 & 229,877 \\
\hline $25-34$ & $2,939,776$ & 189,761 & $3,129,537$ \\
\hline $35-44$ & $6,378,961$ & 506,303 & $6,885,264$ \\
\hline $45-54$ & $6,524,709$ & 801,005 & $7,325,714$ \\
\hline $55-64$ & $4,441,024$ & 789,022 & $5,230,046$ \\
\hline $65+$ & $2,640,010$ & 691,959 & $3,331,969$ \\
\hline JUMLAH & $23,135,967$ & $2,999,502$ & $26,135,469$ \\
\hline
\end{tabular}

Berdasarkan tabel diatas, petani didominasi oleh kelompok umur 35 tahun keatas yaitu sebesar $87,13 \%$, hal ini dapat diasumsikan calon pengguna berusia diatas 35 tahun. KUD (Koperasi Unit Desa) pertanian dan toko pertanian dijadikan pengguna alternatif. Selain sebagai pengguna, KUD dan toko pertanian juga dapat berpartisipasi langsung ke sistem pakar dengan menyediakan daftar dan harga obat pada penyakit padi.

\subsection{Pemilihan Platform Berbasis Web}

Pemilihan platform berbasis web didasari karena berbasis web memiliki keunggulan yaitu sebagai berikut.

a. Lintas platform dan device.

Penggunaan perangkat lunak berbasis web mendukung beberapa tipe perangkat keras seperti komputer, notebook, tablet, maupun smartphone. Perangkat lunak berbasis web juga tidak tergantung pada suatu sistem operasi. Sistem operasi yang digunakan oleh masyarakat mampu untuk membuka situs (website), seperti sistem operasi Windows, Linux, Macintosh, maupun Android.

b. Aplikasi pendukung yang sudah built-in pada sistem operasi dan dapat diunduh secara gratis.

Sistem operasi yang banyak digunakan masyarakat sudah menyertakan aplikasi bawaan pembuka situs (web browser), seperti Internet Explorer, Google Chrome, dan Safari. Aplikasi lain juga dapat didapatkan secara gratis seperti Mozilla Firefox, Opera, dan UC Browser. 
c. Sentralisasi pengolahan data.

Manfaat dari sentralisasi pengolahan data antara lain yaitu validitas data yang disampaikan terjaga, mengurangi waktu proses pengolahan data baik menambah, mengganti maupun menghapus, dan kebutuhan penyimpanan data hanya pada sisi server.

d. Perkembangan teknologi web terus bermunculan dan berkembang.

Perkembangan teknologi web baik framework maupun penunjang teknologi berbasis web terus berkembang dari tahun ke tahun seperti perkembangan PHP, HTML5, Bootstrap, dan lain-lain.

\subsection{Analisis User Environment}

User environment atau lingkungan pengguna yang berkaitan dengan basis web yang paling pokok adalah internet. Internet adalah salah satu syarat utama pengguna dalam mengakses perangkat lunak berbasis web. Menurut survey APJII (Asosiasi Penyelenggara Jasa Internet Indonesia) tahun 2016 [12], Pengguna internet di indonesia berjumlah 132,7 juta dari total populasi penduduk indonesia 256,2 juta jiwa. Pengguna internet dengan rentang umur 3544 tahun sebanyak 38,7 juta dengan persentase $29,2 \%$, rentang umur 45-54 sebanyak 23,8 juta dengan persentase $18 \%$, rentang umur 55 tahun keatas sebanyak 13,2 juta dengan persentase $10 \%$. Peningkatan pengguna dengan rentang umur 35 tahun keatas sangat meningkat dibandingkan survey pada tahun 2014, rentang umur 35-44 dari 14,6\% meningkat menjadi $29,2 \%$, rentang umur $45-55$ dari 2,4\% meningkat menjadi $18 \%$, dan rentang umur 55 keatas dari $0,2 \%$ meningkat menjadi $10 \%$. Grafik pengguna internet berdasarkan rentang usia dapat dilihat pada gambar 2 berikut ini.

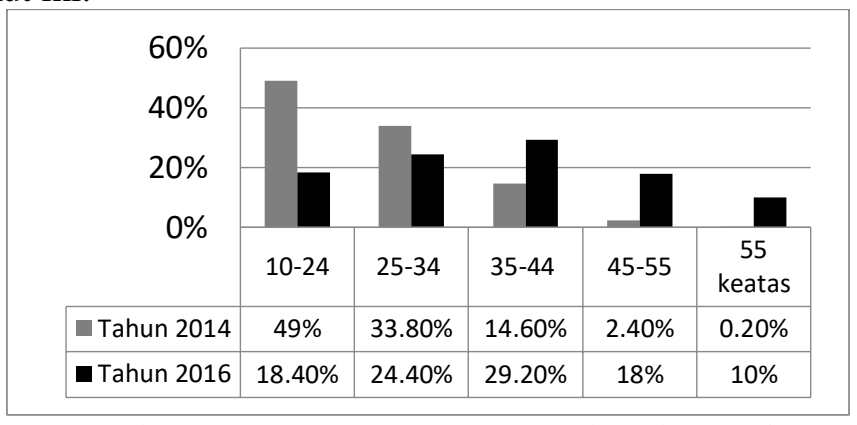

Gambar 2. Pengguna Internet Berdasarkan Usia

Berdasarkan perkembangan pengguna internet berdasarkan usia, petani yang didominasi umur 35 tahun keatas berdasarkan pada tabel 1 sebesar 87,13\%, dapat diasumsikan sebagian petani tersebut termasuk dalam pengguna internet pada rentang usia 35 tahun keatas yang mengalami peningkatan dibandingkan pada tahun 2014. Hal ini juga menjadi faktor pendorong dalam pengembangan sistem pakar penyakit padi berbasis web.

\subsection{Perancangan Struktur Menu}

Rancangan struktur menu pada sistem pakar penyakit padi yang akan dibuat model antarmuka dapat dilihat pada gambar 3 berikut ini.

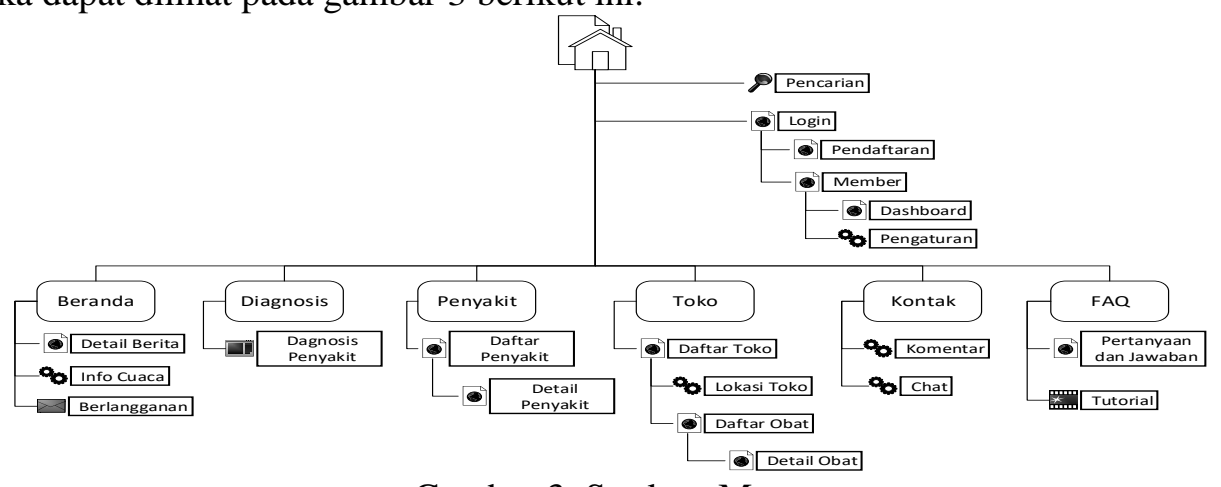

Gambar 3. Struktur Menu 
Tipe pengguna pada rancangan sistem pakar ini dibagi menjadi 4 katagori, yaitu pengunjung, member, toko, dan admin. Pengunjung adalah pengguna yang mengunjungi web sistem pakar tanpa melalui proses pendaftaran dan login, pengunjung dapat melihat semua sub menu pada sistem pakar, akan tetapi pengunjung pada menu kontak hanya dapat memberikan komentar, fitur chat tidak tersedia pada pengunjung. Member merupakan pengunjung yang melalui proses pendaftaran dan login, member dapat melakukan interaksi dengan admin sistem menggunakan fitur chat apabila ada pertanyaan atau saran yang ingin disampaikan. Toko dapat memasukan data daftar nama obat atau pestisida berserta harga untuk penyakit padi dan alamat toko kedalam sistem pakar. Toko dapat merubah data harga maupun daftar obat yang telah buat oleh toko tersebut. Admin memasukkan pengetahuan yang berasal dari pakar ke dalam sistem tentang ciri-ciri serta peraturan berbasis pengetahuan pada diagnosa penyakit padi, pengobatan serta penanggulangan penyakit padi dan berita maupun metode-metode baru bidang pertanian kedalam sistem pakar.

Pada perancangan ini menggunakan metode inferensi forward chaining yang melakukan pencarian dari suatu masalah yang berawal dari gejala-gejala penyakit padi kemudian ditemukan solusi yang berupa nama penyakit padi pada halaman detail penyakit padi. Diagram alur pada sistem pakar dapat dilihat pada gambar 4 berikut ini.

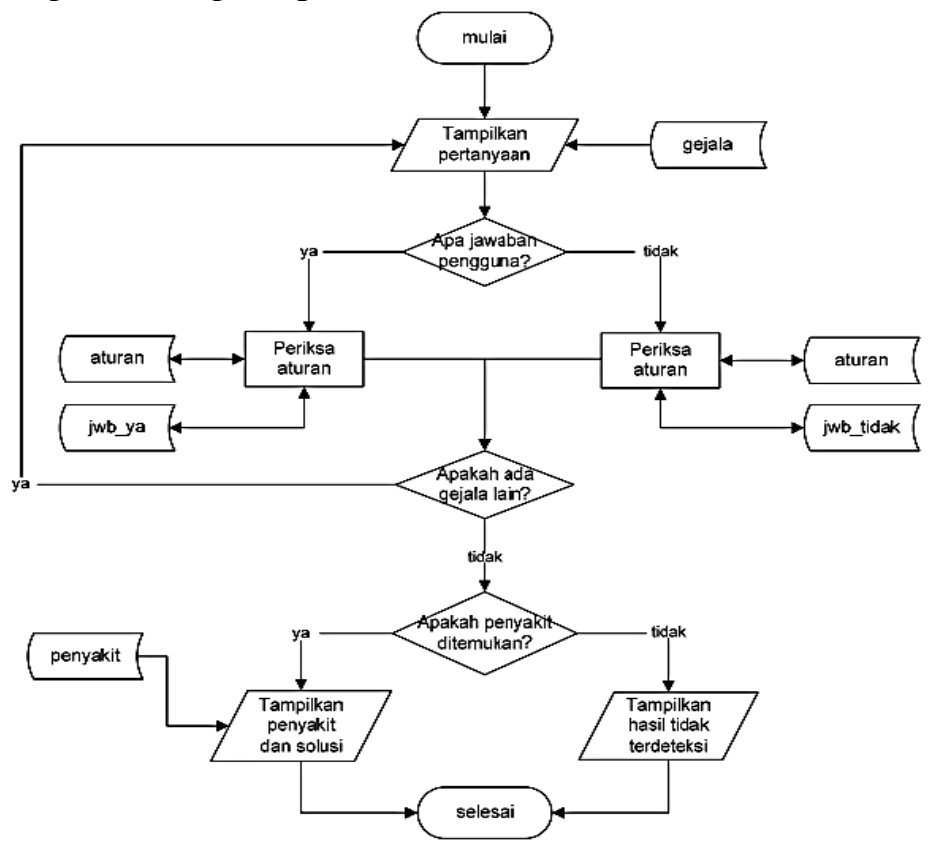

Gambar 4. Diagram Alur Sistem Pakar

Sistem pakar yang dirancang menggunakan penalaran berbasis aturan. Tabel penyakit pada sistem pakar dapat dilihat pada tabel 3 dan tabel gejala dapat dilihat pada tabel 4 berikut ini.

Tabel 3. Tabel Penyakit

\begin{tabular}{ll}
\hline P1 & Tungro \\
\hline P2 & Kerdil Rumput \\
\hline P3 & Kerdil Hampa \\
\hline P4 & Blast \\
\hline P5 & Bercak Coklat \\
\hline P6 & Hawar Pelepah \\
\hline P7 & Hawar Bakteri \\
\hline P8 & Daun Jingga \\
\hline P9 & Kerdil Kuning \\
\hline
\end{tabular}

Tabel 4. Tabel Gejala 
Febrianta Surya Nugraha, Febryan Hari Purwanto, Mayadi, Miftahul Huda, Muhammad Misbahul Munir, Riski Tri Puji

\begin{tabular}{|c|c|}
\hline G2 & Anakan berkurang / sedikit \\
\hline G3 & Daun menguning sampai jingga dari pucuk ke pangkal \\
\hline G4 & Daun muda terllihat seperti mottle \\
\hline G5 & Daun tua seperti bintik-bintik coklat bekas ditusuk \\
\hline G6 & Bercak bercak warna coklat \\
\hline G7 & Anakan bertambah banyak \\
\hline G8 & Daun pendek dan sempit \\
\hline G9 & Daun berwarna hijau pucat / kekuning kuningan \\
\hline G10 & Bercak menyerang daun \\
\hline G11 & Anakan tumbuh tegak \\
\hline G12 & Daun melingkar seperti terpilin \\
\hline G13 & Helai daun bergerigi \\
\hline G14 & Daun bendera robek robek / berombak ombak sepanjang pembuluh \\
\hline G15 & Daun berwarna hijau tua \\
\hline G16 & Gabah yang dihasilkan hampa / kosong \\
\hline G17 & Malai keluar sebagian \\
\hline G18 & Bercak berbentuk oval / elips \\
\hline G19 & Bercak berwarna kelabu / keputihan \\
\hline G20 & Bercak dilingkari warna coklat / merah kecoklatan \\
\hline G21 & Pangkal leher malai berwarna coklat keabu abuan \\
\hline G22 & Daerah dekat leher panikel berwarna coklat \\
\hline G23 & Bercak hitam / coklat pada kulit gabah \\
\hline $\mathrm{G} 24$ & Bercak pada pelepah daun bagian bawah \\
\hline G25 & Bercak berwarna abu abu kehijauan / hijau keabu abuan \\
\hline G26 & Tepi daun luka berupa garis bercak kebasahan \\
\hline G27 & Daun keriput dan layu seperti tersiram air panas \\
\hline G28 & Daun menggulung dan mengering \\
\hline G29 & Daun berwarna abu abu keputih putihan \\
\hline G30 & Daun tua normal, daun muda pucat klorosis \\
\hline G31 & Daun berwarna jingga \\
\hline G32 & Akar tanaman lebih sedikit \\
\hline G33 & Daun berwarna hijau pucat / kuning pucat \\
\hline G34 & Anakan tumbuh lemas \\
\hline
\end{tabular}

Aturan pada sistem pakar digambarkan dengan diagram pohon keputusan yang dapat dilihat pada gambar 5 berikut ini.

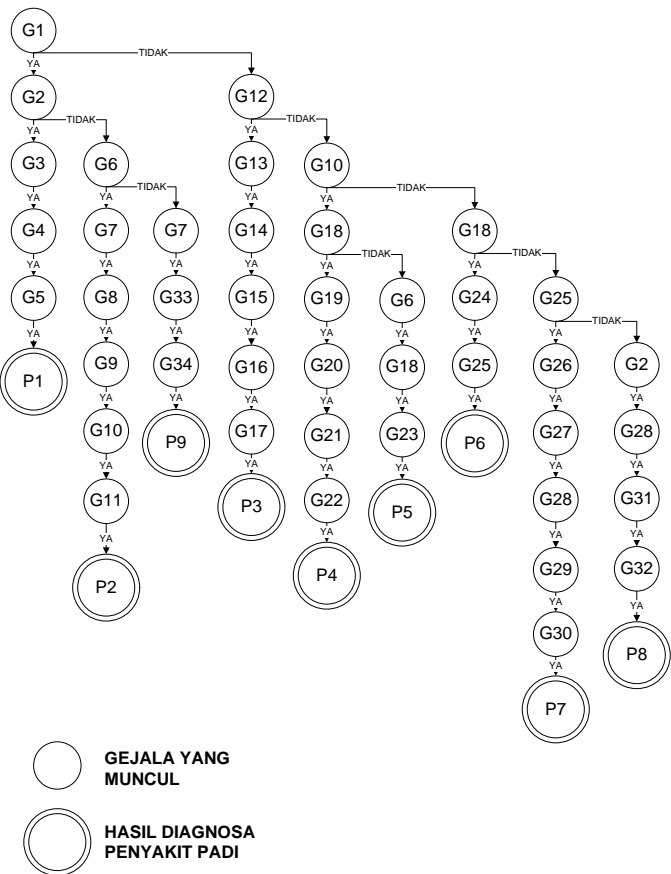

Gambar 5. Diagram Pohon Keputusan Sistem Pakar Penyakit Padi 
Dari halaman detail penyakit padi, pengguna dapat memilih untuk menuju halaman detail obat yang berisi nama obat dari penyakit hasil diagnosa serta cara penggunaan obat tersebut. Dari halaman detail obat, pengguna dapat memilih untuk menuju halaman daftar toko dimana obat tersebut tersedia dalam data sistem pakar. Rancangan relasi tabel yang akan digunakan dalam sistem pakar penyakit padi ini dapat dilihat pada gambar 6 berikut ini.

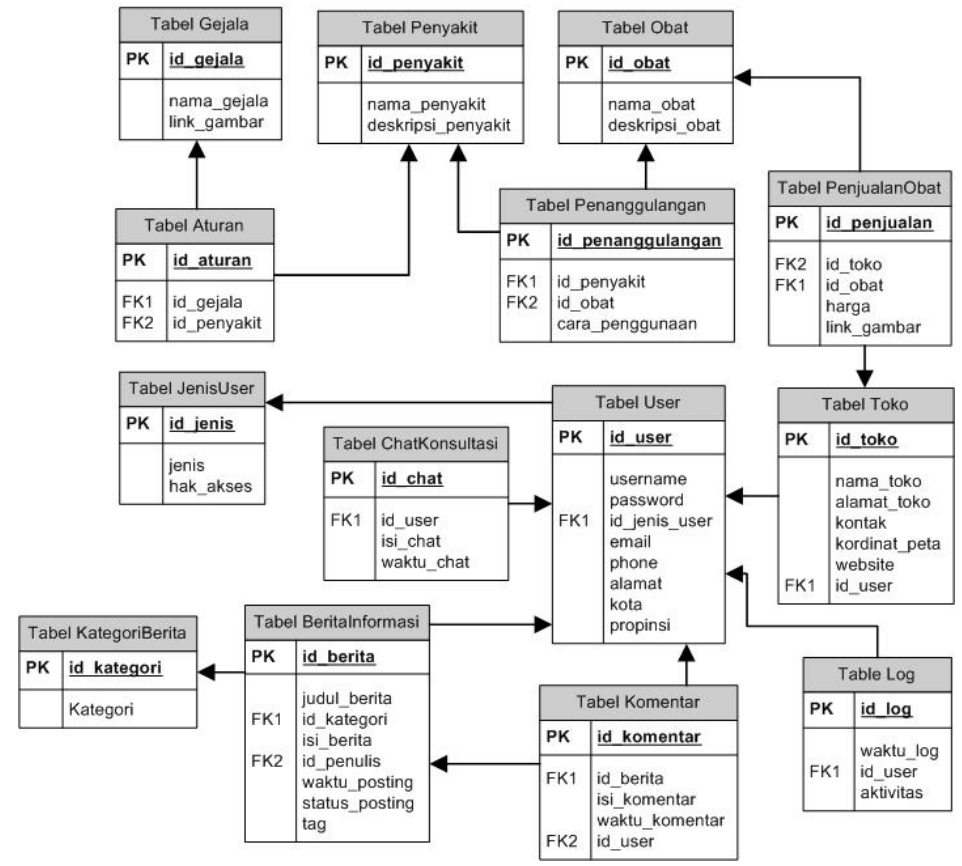

\subsection{Perancangan Antarmuka}

Gambar 6. Relasi Tabel

Aspek penggunaan jenis perangkat keras yang digunakan untuk membuka rancangan web sistem pakar penyakit padi perlu diperhatikan secara menyeluruh. Perancangan halaman berdasarkan ukuran perangkat kerat seperti desktop, tablet, dan mobile bertujuan supaya tampilan rancangan yang dibangun tidak rusak atau tidak berfungsi dengan baik apabila dibuka dengan resolusi layar perangkat keras yang berbeda, Perancangan antarmuka dibuat dalam 3 ukuran disesuaikan dengan perangkat keras yaitu ukuran desktop. tablet, dan mobile. Rancangan halaman utama dapat dilihat pada gambar 7 berikut ini.
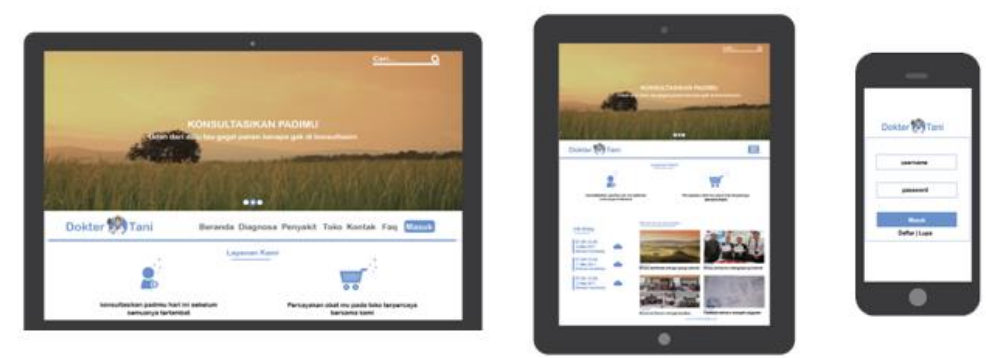

Gambar 7. Rancangan Halaman Utama

Member, toko dan admin yang terdaftar untuk dapat masuk atau login kedalam sistem pakar melalui halaman masuk. Pada halaman utama terdapat berita maupun informasi terbaru dan beberapa menu yang terdapat di website sistem pakar yaitu pencarian, login, beranda, diagnosis, penyakit, toko, kontak, FAQ. Pada menu beranda, pengguna dapat melihat detail berita berupa informasi yang berkaitan dengan pertanian khususnya tanaman padi, informasi kegiatan, bantuan, penyuluhan yang dapat diikuti atau infomasi lainnya yang berkaitan dengan 
teknologi pertanian. Selain itu, di menu beranda terdapat sub menu info cuaca yang bersumber dari data website BMKG (Badan Meteorologi, Klimatologi dan Geofisika) serta sub menu berlangganan bagi pengunjung website sistem pakar yang ingin mendapatkan informasi melalui email apabila terdapat update atau berita maupun pembaharuan website sistem pakar. Rancangan halaman beranda dapat dilihat pada gambar 8 berikut ini.
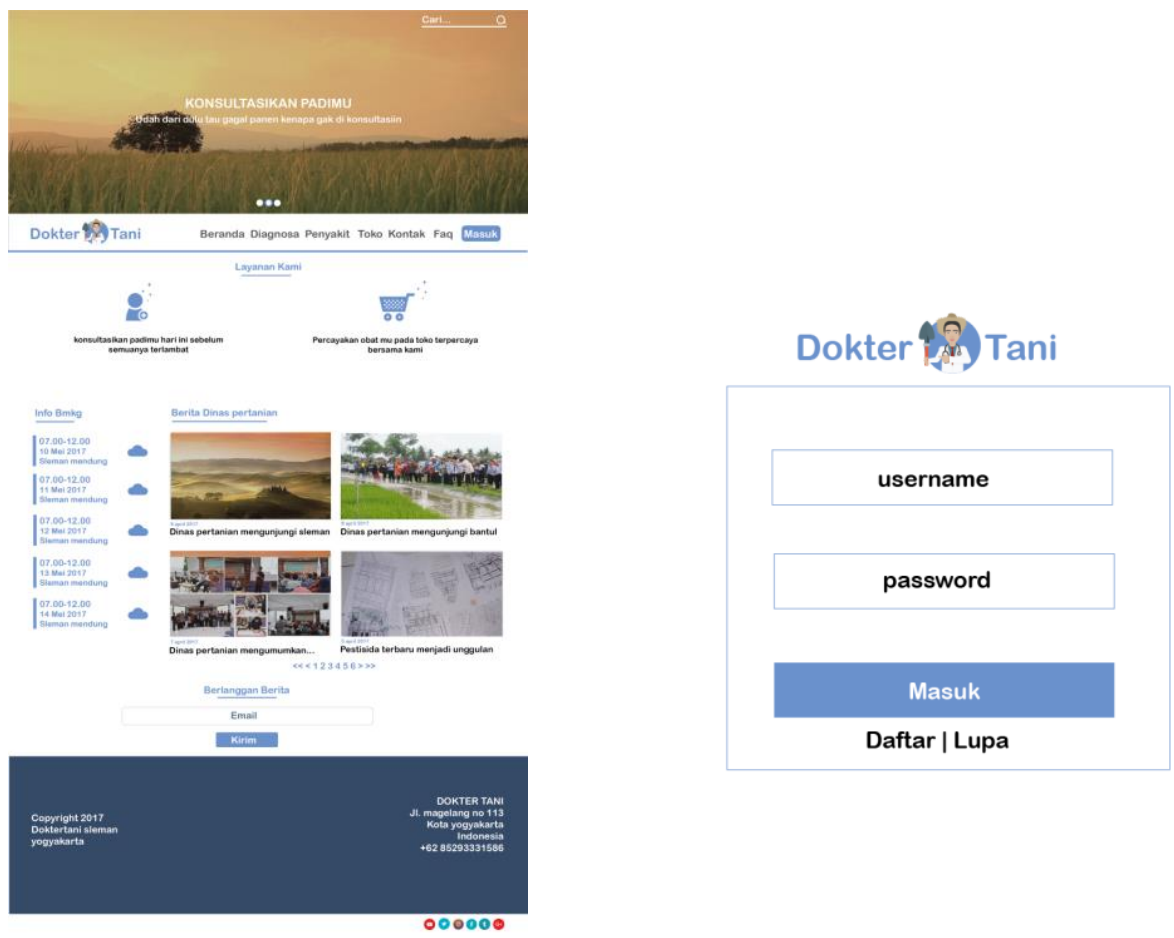

Gambar 8. Rancangan Halaman Beranda dan Masuk

Pada menu diagnosis, pengguna dapat melakukan diagnosa penyakit padi yaitu memilih gejala yang timbul pada tanaman padi untuk diproses kemudian akan ditampilkan hasil diagnosa penyakit. Pada halaman hasil diagnosis, selain menampilkan hasil dan detail dari proses diagonsis, pada halaman ini juga terdapat link menuju ke halaman obat, cara pengendalian, maupun melakukan proses diagnosis ulang. Rancangan halaman menu diagnosis dan hasil diagnosis dapat dilihat pada gambar 9 berikut ini.
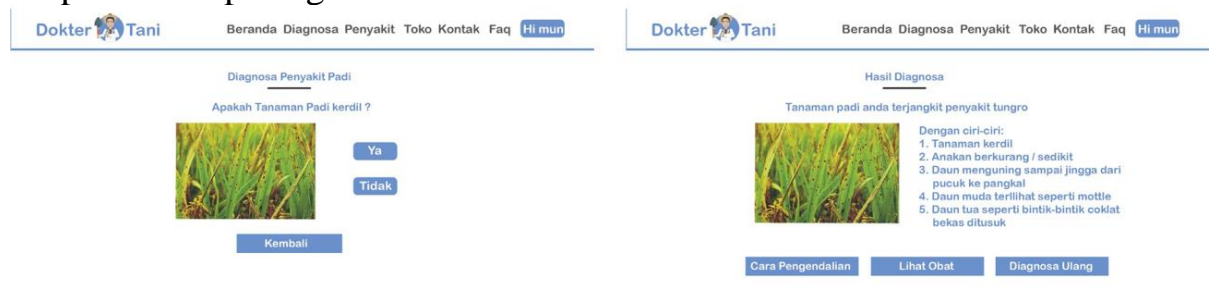

Gambar 9. Rancangan Halaman Diagnosis dan Hasil Diagnosis

Dari halaman detail penyakit padi, pengguna dapat memilih untuk menuju halaman detail obat yang berisi nama obat dari penyakit hasil diagnosa serta cara penggunaan obat tersebut. Dari halaman detail obat, pengguna dapat memilih untuk menuju halaman daftar toko dimana obat tersebut tersedia dalam data sistem pakar. Rancangan halaman penyakit dan toko dapat dilihat pada gambar 10 berikut ini. 


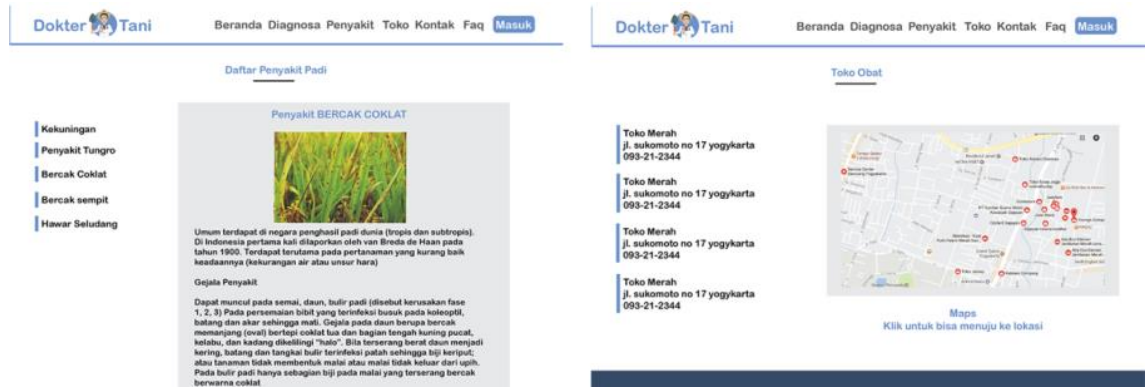

Gambar 10. Rancangan Halaman Penyakit dan Toko

Pada menu penyakit, pengguna dapat melihat daftar penyakit pada tanaman padi beserta detailnya. Pada menu toko, pengguna dapat melihat sub menu daftar toko, yang apabila di klik maka pengguna dapat mengetahui informasi lokasi toko tersebut, daftar obat yang dijual pada toko tersebut beserta detailnya. Pada menu kontak, pengguna dapat melihat sub menu komentar dan chat yang berfungsi sebagai wadah bertanya, kritikan atau masukkan yang ditujukan kepada admin atau ke pakarnya itu sendiri. Pada menu FAQ, pengguna dapat melihat beberapa pertanyaan yang sudah berisi jawaban seputar website sistem pakar dan informasi pertanian, selain itu juga terdapat video tutorial penggunaan sistem pakar. Rancangan halaman kontak dan FAQ dapat dilihat pada gambar 11 berikut ini.

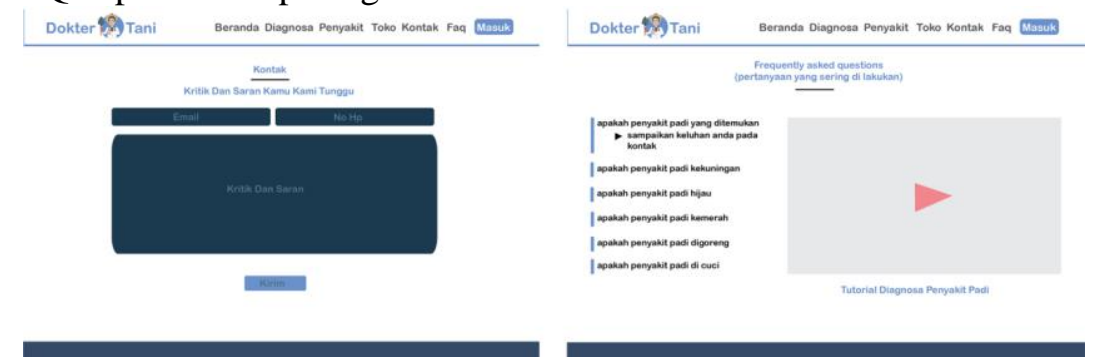

Gambar 11. Rancangan Halaman Kontak dan FAQ

\subsection{Evaluasi}

Evaluasi dilakukan dengan pendekatan evaluasi heuristik penggunaan (usability heuristics) dengan kriteria pada Tabel 1 yaitu daftar heuristik [4] secara focus group discussion dengan 4 orang sebagai evaluator. Anggota focus group discussion berasal dari mahasiswa Magister Teknik Informatika Universitas Amikom Yogyakarta yang dipilih secara acak pada presentasi perancangan antarmuka sistem pakar penyakit padi berbasis web dalam matakuliah rekayasa perangkat lunak dengan tema human computer interaction (interaksi manusia dan komputer). Tujuan dari focus group discussion adalah mencari kekurangan rancangan antarmuka pengguna serta memberikan masukan berupa saran untuk rancangan antarmuka sistem pakar. Kesimpulan dari hasil evaluasi heuristik penggunaan antara lain sebagai berikut.

1. Visibilitas status sistem

Pada aspek visibilitas status sistem, rancangan antarmuka sudah menampilkan judul halaman di setiap halaman untuk memudahkan mengenali halaman yang dibuka oleh pengguna. Saran pada aspek ini adalah pemberian warna menu yang berbeda pada menu yang sedang dibuka atau dipilih oleh pengguna sehingga dapat menambah aspek visibilitas status sistem selain dari pemberian judul halaman.

2. Kesesuaian antara sistem dan dunia nyata

Pada aspek kesesuaian antara sistem dan dunia nyata, pada rancangan antarmuka masih banyak ditemui kata-kata berbahasa Inggris seperti username, password, FAQ serta penggunaan kata yang tidak baku yaitu diagnosa yang dapat menyebabkan pengguna sulit untuk memahami sehingga dalam penggunaan kata-kata sebaiknya berbahasa Indonesia yang lazim dikenal oleh masyarakat.

3. Kendali dan kebebasan pengguna 
Rancangan antarmuka sudah memenuhi aspek kendali dan kebebasan pengguna yaitu pemberian tombol kembali pada pertanyaan sistem pakar sehingga memudahkan pengguna untuk kembali ke pertanyaan sebelumnya apabila pengguna merasa salah dalam memilih jawaban dari pertanyaan sistem pakar.

4. Standar dan konsistensi

Standar dan konsistensi rancangan antarmuka sudah memenuhi dengan penggunan tema, warna, dan kata-kata yang konsisten pada keseluruhan rancangan antarmuka.

5. Pencegahan kesalahan

Pemberian keterangan peringatan sebelum pesan kesalahan sudah terdapat pada menu daftar dan masuk sehingga dapat membantu pengguna dalam melakukan pendaftaran dan mengingatkan pengguna pada bagian yang harus diisikan tetapi belum terisi secara benar.

6. Memahami lebih baik daripada mengingat

Petani sebagai calon pengguna masih banyak yang masuk dalam kategori buta huruf dan berusia tua yang agak terganggu penglihatannya sehingga perlu bantuan ikon maupun gambar untuk memudahkan pengguna dalam mengenali tombol. Perlunya perbedaan yang jelas antara tombol dan tulisan untuk mempermudah pengguna dalam mengenali tombol.

7. Fleksibilitas dan efesiensi

Pemilihan struktur menu yang sederhana dengan jumlah sub menu yang sedikit membuat rancangan antarmuka sudah memenuhi aspek efisiensi dan fleksibilitas. Pengguna dapat berpindah ke menu lain hanya dengan satu langkah dengan memilih tombol menu pada bagian atas tampilan rancangan antar muka.

8. Estetika dan desain yang minimalis

Penggunaan warna latar putih dengan variasi warna yang sedikit memberi kesan tampilan yang minimalis serta tidak terdapat tampilan-tampilan yang tidak diperlukan pada halaman sehingga tidak menimbulkan gangguan pandangan dalam melihat antarmuka. Saran pada aspek ini adalah penggunaan warna yang berkaitan atau berhubungan dengan pertanian maupun tanaman padi.

9. Pertolongan pengguna untuk mengenali, berdialog dan memperbaiki kesalahan

Pemberian pesan kesalahan apabila member gagal untuk masuk kedalam sistem sudah ada, akan tetapi saran yang didapatkan adalah pemberian keterangan apakah nama pengguna tersebut terdaftar atau tidak saat pada proses masuk sehingga pengguna dapat mengetahui apakan kata sandi pengguna salah atau memang nama pengguna tersebut belum terdaftar kedalam sistem.

10. Bantuan dan dokumentasi

Pemberian halaman FAQ pada rancangan antarmuka ini sudah memenuhi aspek bantuan dan dokumentasi. Saran pada aspek ini adalah pemberian peta situs dan diskripsi keterangan halaman pada menu-menu.

\section{KESIMPULAN}

Kesimpulan dari penelitian ini antara lain perancangan antarmuka sistem pakar penyakit padi berbasis web terdiri dari menu beranda, diagnosis, penyakit, toko, kontak, dan FAQ. Berdasarkan hasil evaluasi, kekurangan pada rancangan antarmuka sistem pakar penyakit padi berbasis web adalah sebagai berikut: a) Penggunaan kata-kata berbahasa Inggris seperti username, password, login, FAQ serta penggunaan kata yang tidak baku yaitu diagnosa pada aspek kesesuaian antara sistem dan dunia nyata; b) Kurangnya penggunaan ikon pada menu pada aspek memahami lebih baik daripada mengingat; c) Perbedaan tombol dan teks yang kurang jelas pada aspek memahami lebih baik daripada mengingat; d) Pesan kesalahan yang muncul kurang detail pada aspek pertolongan pengguna untuk mengenali, berdialog dan memperbaiki kesalahan. 


\section{SARAN}

Saran dari penelitian perancangan antarmuka sistem pakar penyakit padi berbasis web adalah sebagai berikut: a) Pemberian warna menu yang berbeda pada menu yang sedang dibuka atau dipilih oleh pengguna sehingga dapat menambah aspek visibilitas status system; b) Penggunaan kata-kata berbahasa Indonesia yang lazim dikenal oleh masyarakat; c) Pemberian ikon pada menu; d) Perlunya perbedaan yang jelas antara tombol dan tulisan; e) Penggunaan warna yang berkaitan atau berhubungan dengan pertanian maupun tanaman padi; f) Pemberian pesan kesalahan secara detail; dan g) pemberian peta situs dan diskripsi keterangan halaman.

\section{DAFTAR PUSTAKA}

[1] Rosenelly, R., dan Utama, U. P., 2012, Sistem Pakar : Teori dan Konsep, Andi Offset, Yogyakarta.

[2] Hayadi, B. H., dan Rukun, K., 2016, What is Expert System, Deepublish, Yogyakarta.

[3] Sulianta, F., 2010, IT Ergonomics : Menjadi Sehat dan Produktif dalam Kantor Berbasis Teknologi Informasi, Elex Media Komputindo, Jakarta.

[4] Wilson, C., 2013, User Interface Inspection Methods: A User-Centered Design Method, Elsevier Science.

[5] Aziah, N., Syarah, dan Setiawati, P. D., 2013, Rancang Bangun Aplikasi Sistem Pakar Diagnosa Penyakit Tanaman Padi Berbasis Web, Jurnal Computer Science Research and Its Development, Vol. 5 No. 1, 63-74, : http://csrid.potensiutama.ac.id/index.php/CSRID/article/view/37/36.

[6] Saepulloh, A., dan Fatimah, D. D. S., 2016, Pengembangan Sistem Pakar Diagnosis Penyakit dan Hama pada Tanaman Padi Varietas Sarinah Berbasis Android, Jurnal Algoritma Sekolah Tinggi Teknologi Garut, Vol. 13 No. 1, 149-156, : http://jurnal.sttgarut.ac.id/index.php/algoritma/article/view/318.

[7] Triono, J., dan Tristono, T., 2016, Expert System Identification of Pest and Diseases of Rice using Html5, International Journal of Advanced Research in Computer Science, Vol 7, No. 3, 60-63, : http://ijarcs.in/index.php/Ijarcs/article/viewFile/2667/2655.

[8] Firmansyah, R., 2016, Evaluasi Heuristik Pada Desain Interfae Aplikasi My Indihome, Prosiding Seminar Nasional Ilmu Pengetahuan dan Teknologi Komputer Nusa Mandiri, Vol. 4, No. $\quad 1$, 66-73, http://konferensi.nusamandiri.ac.id/prosiding/index.php/sniptek/article/view/11/11.

[9] Savitri, P., dan Ispani, M., 2015, Review Desain Interface Aplikasi Sopppos Menggunakan Evaluasi Heuristik, Simetris: Jurnal Teknik Mesin, Elektro dan Ilmu Komputer, Vol. $\quad 6, \quad$ No. $1, \quad 95-100$, http://jurnal.umk.ac.id/index.php/simet/article/viewFile/243/241.

[10] Pattiasina, G., Tanazale, B., dan Tjahyana, L. J., 2014, Pembuatan Dan Evaluasi Kemudahan Turis Dalam Menggunakan Aplikasi Baronda Ambon Travel Guide, Scriptura: Jurnal Ilmiah, Vol. 4, No. 1, 29-37, : http://ced.petra.ac.id/index.php/iko/article/view/19053/18686.

[11] Badan Pusat Statistik, 2013, Jumlah Rumah Tangga Usaha Pertanian Menurut Kelompok Umur Dan jenis Kelamin Petani Utama Tahun 2013, https://st2013.bps.go.id/dev2/index.php/site/tabel?tid=25\&wid=0 , diakses tanggal 16 April 2017.

[12] APJII (Asosiasi Penyelenggara Jasa Internet Indonesia), 2016, Infografis Penetrasi dan Perilaku Pengguna Internet Indonesia 2016, https://apjii.or.id/survei2016, diakses tanggal 30 April 2017. 